\title{
Trado-Modern Communication: Catalyst for Prevention of Mother-To-Child Transmission of HIV/AIDS Among Andoni Women
}

\author{
Ata-Awaji Anthony Reuben, \\ B.A (Nigeria), M.A (UPH) \\ Lecturer, Salem University, Lokoja, Kogi State, Nigeria
}

\begin{abstract}
This work relied on empirical submissions by scholars and made a case for the fusion of modern and traditional modes of communication in the fight against HIV/AIDS that has continued to plague people living in Nigeria, especially those in its rural areas. So, the work discusses the synthesis of traditional and modern methods of communication as catalyst for prevention of mother-to-child transmission of HIV/AIDS among Andoni women, due to their precarious situations being residents of rural areas amid illiteracy, cultural values and beliefs. The work adopted Diffusion of Innovation Theory as anchor for the discourse. After exploring the various submissions concerning the merits emanating from the fusion of the two media systems, putting them side-byside with the peculiar nature of rural people in Nigeria, using Andoni as a case study, it concludes that tradomodern communication is a better communication strategy that should be adopted in the fight against the disease, based on empirical facts concerning their strength in awareness creation, advocacy and spread of innovation in the society.
\end{abstract}

Keywords: Trado/modern communication, Catalyst, Prevention, HIV/AIDS, Andoni women

DOI: $10.7176 / \mathrm{JCSD} / 55-05$

Publication date: January $31^{\text {st }} 2020$

\section{Introduction}

Human Immune Virus and Acquired Deficiency Syndrome (HIV/AIDS) is no longer among the world's top 10 causes of death, according to World Health Organization (WHO). However, it remains threatening and has continued to gain global attention, due to its mode of infection and spread. In Nigeria the disease remains very challenging because the country has the second largest HIV epidemic in the world. According to the National Agency for the Control of Aids, although HIV prevalence among adults in Nigeria is much less $(2.8 \%)$ than other sub-Saharan African countries such as South Africa with 18.8 per cent and Zambia 11.5 per cent, the size of Nigeria's population means 3.1 million people were living with HIV in 2017. Also, it has been said that Nigeria accounts for about half of all new HIV infections in sub-Saharan Africa despite achieving a 5 per cent reduction in new infections between 2010 and 2017.

According to https://www.vanguardngr.com, retrieved on December 18, 2019 the National Agency for the Control of AIDS lamented that Nigeria had fallen below 40 per cent in achieving the first 90 target of the Joint United Nations Programme on HIV/AIDS (UNAIDS), tagged 90-90-90 response to HIV treatment. The Joint United Nations Programme on HIV/AIDS and partners launched the 90-90-90 target in 2014 to advance response to HIV and AIDS treatment. The plan is to ensure that 90 per cent of all HIV positive persons are diagnosed, provided the antiretroviral therapy for 90 per cent of those diagnosed, and to achieve viral suppression for 90 per cent of those treated by 2020 .

This is why the syndrome is still a threat to the world and requires constant efforts and study to contend its transmission and spread. And because around the world, women are increasingly at risk from HIV and bear the brunt of stigma and discrimination, they often lack freedom of choice. They sometimes find it harder to avoid HIV infection (Oyesomi, 2010, P. 108). Among its avenues for spread is the Mother-to-child transmission, which is the spread of HIV from an infected pregnant woman to her foetus and/or child during pregnancy, or through breastfeeding. This, according to medical experts, is the most common way that children become infected with the virus. Meanwhile, according to the National Agency for the Control of Aids, 26.9 per cent of all cases of mother-to-child transmission of HIV in the world happen in Nigeria. South-South region of the country is said to have the highest HIV prevalence in Nigeria, and Rivers State is one of the states in the region. The prevalence of HIV/AIDs in Rivers State is about 5.8, while Mother-to-Child Transmission is 1 per cent, according to government source. Rivers State has most of her population in the rural areas. According to National Agency for the Control of Aids, the rural area in Nigeria has higher rates of HIV than the urban centres. This revelation is worrisome and makes it imperative for serious attention to be given to the area that has continued to dominate discourse in terms of its precarious situation.

Human Immune Deficiency Virus (HIV) is a causative agent of Acquired Immune Deficiency Syndrome (AIDS). AIDS is regarded by medical experts globally as the most deadly sexually transmitted disease. 
According to the World Health Organization, cited in Nwagbo and Ubachukwu (2001, p. 346), "the seriousness of AIDS as a sexually transmitted disease stems not only from the fact that known cure has not been proffered to date'. AIDS was first reported in the United States of America in 1981, while according to Momoh, cited in Nwagba and Ubachukwu (2001), the first confirmed AIDS case in Africa was reported in Nairobi, Kenya while the concern about HIV infection and AIDS in Nigeria was raised in 1984 (p. 346). Since then till now the endemic disease has continued to pose very serious health, economic and socio-cultural concerns to the government of Nigeria and the people. AIDS is, therefore, seen as a threat to the society with billions of naira spent by government every year to control its spread and to reduce the risks of carriers dying of the disease.

Nigeria as a developing country has most of her population in the rural areas where cases of AIDS are more pronounced than in the urban areas. This has continued to pose socio-cultural, economic and religious concern to government and the people. However, ignorance, illiteracy and lack of adequate information and awareness about the prevalence, spread and control of the disease, especially in the rural areas of Nigeria have remained issues to be addressed. To address the ignorance and raise awareness among the people concerning the danger of the disease, communication experts believe that adequate and appropriate communication strategies should be adopted:

The central role of communication in the global war on HIV/AIDS has been very obvious. Since the outbreak of the epidemic, communities or the media in particular have played key roles in awareness creation, enlightenment, motivation, education, and persuasive advocacy among others. Communication is widely acknowledged as a powerful force for positive change. It is a very powerful tool for fostering learning as well as a tool for enhancing people's quality of life...(Jibril, Suleiman, Abdullahi and Mohammed 2018, p.506).

It appears some communities, by virtue of their occupational callings and cultural life, may be more vulnerable to the scourge than others. It also appears that some specific channels of communication can be better utilized for achieving the goals of HIV/AIDS control, especially among some selected communities (p.504).

It is in view of the above submissions that this works seeks to analyze the positions of trado-modern communication for prevention of mother-to-child transmission of HIV/AIDS among Andoni women in Rivers State, Nigeria.

\section{Theory}

Diffusion of Innovation Theory is adopted for this work. Rogers originally wrote about this theory in the book, Diffusion of Innovation, published in 1962. Together with Shoemaker, the theory was further presented as the Communication of New Ideas in 1971, Ojobor (2016). Also writing on how Diffusion of Innovation Theory came about, Baran and Davies (2007) narrate that:

In 1962, Everett Rogers combined the information-flow research finding with studies about the flow of information and personal influence in several fields, including anthropology, sociology, and agricultural extension work. He developed what he called diffusion theory, which can be seen as an extension of Lazarsfeld original idea of the two-step flow. Roger's effort at integrating information-flow research with diffusion theory was so successful that information-flow theory became information diffusion theory and when it is applied to the diffusion of something other than information that is technology, it is called innovation diffusion theory (p.173).

According to Rogers and Shoemaker (1971) diffusion is the process by which innovations spread to the members of a social system (p.12). Innovation, therefore, passes through stages before it is being adopted as explained by Baran and Davies:

Rogers assembled data from numerous empirical studies to show that when new technological innovations are introduced, they will pass through a series of stages before being widely adopted. First, most people will become aware of them, often through information from mass media. Second, the innovations will be adopted by a very small group of innovators, or early adopters. Third, opinion leaders learn from early adopters and try the innovation themselves. Fourth, if opinion leaders find the innovation useful, they encourage their friends-the opinion followers. Finally, after most people have adopted the innovation, a group of laggards or late adopters make the change... (p.173)

According to Asadu (2012) diffusion of innovation theory came about following the modification of the modernization paradigm. He asserts that: 
Rogers, a social scientist, by way of modifying modernization paradigm reasoned that for people to change from traditional to modern society they need to adopt new ideas, technologies, innovators and practices even without getting directly exposed to the media. This he called diffusion of innovation. Asadu continues by saying that the mass media will create the awareness of ideas and interpersonal communication will be used to persuade the people to adopt the innovation. He defines diffusion of innovation as the communication of innovation through certain channels overtime among members of a social system with certain effects (p.38)

Innovation, being a noble idea, lofty conception and action, is also a development initiative intended to impact positively on the people. To impact on the lives of the people, therefore, it must be diffused, synthesized and adopted. This is tied to communication. So, diffusion is a communication function of spreading development idea. The development idea will bring about social change and people gaining control over their environment.

Wogu (2008) makes a revealing assertion about Diffusion of Innovation Theory. He says that diffusion theory is a source-dominated theory that sees the communication process from the point of view of elite that has decide to diffuse an innovation. This theory improves upon information flow theory by providing more and better strategies for overcoming barriers to innovations. Diffusion theory assigns a very limited role to mass media: media mainly create awareness of innovation. Only the early adopters are directly influenced by media content. Others adopt innovations only after being influenced by other people. Rogers recommended that agents lead diffusion efforts, people who could go out in rural communities and directly influence early adopters and opinion leaders (p. 165).

In diffusion of innovation, interests in diverse form also contribute to its effectiveness. The other source of influence is more diffusing but often effective. It stems from the many interests, especially economic but also cultural and social, that are effected by the mass media, particularly in respect of news and information. Powerful individuals and organisations can be hurt by the news and may also need it to further their ends. For this reason, they keep a close eye on media conduct for their own protection or seek to influence it. All in all, this adds up to an environment of expectation and scrutiny that has considerable cumulative influence (McQuail 2005 p. 163). MaQuail continues by contending that although media are freely chosen by their audiences, actual people in audiences may not have personally chosen their media or the specific content to which they find themselves exposed (p. 443). Audiences are connected to 'Distant' media sources in several ways, perhaps especially through the mediation of their family, friends and others in their social milieu (p. 445).

The above assertion shows that diffusion of innovation theory recognizes differences in individuals, perceptions and interests. Therefore, acceptance of an idea, programme and initiative may pass through stages and time based on human behaviour and exposure, family background, social, political, economic and religious system to which an individual belongs.

The theory describes how new ideas, information and culture are passed from people to people or from one geographical area to another. It involves a system of explanation on how freely, slowly or rapidly people in a society accept new ideas, depending on time, nature of media of communication and demographic variables of the target audience. This theory explains the development of nations and the spread of different cultures, Nwanne, in Mboho and Batta (2012).

A critical perusal of this theory amidst the reality of Mother-To-Child Transmission of AIDS reveals the interconnectedness between the theory and the study. Mother-To-Child Transmission of AIDS is not an abstract thing. It involves physiological process which requires people's awareness and consciousness for its prevention and elimination. In fact, its success depends largely on the people's understanding and acceptance of methods and measures that have been put in place to prevent the spread of the virus. People differ in attitude and perception, and are constantly staying glued to their values, customs and other cultural underpinnings, for a change in attitude or for upholding of behaviour. This explains why the researcher adopted the theory for this study.

\section{Andoni as a Rural Area of Rivers State}

Andoni Local Government Area by location and comparison with other Local Government Areas of Rivers State is in the rural area. It is also the least developed area in Rivers State. According to the 2006 National Population Census, the population of Andoni is 217,924 . The area covers $233 \mathrm{~km} 2$, largely surrounded by sea. People of the area are predominately anglers (fishermen and women). As it is typical of rural people, the people of Andoni lack electricity, good health care centres, portable water and motorable roads, among others. Andoni, no doubt, is a rural area in view of the conceptualization of rural area by experts. In his view, Udoakah (1998) notes that:

the word rural brings to mind geographic locations in Africa with populations of hungry, wretched looking people and stunted, kwashiorkor riddled children. It conjures the image of a people who suffer in the farm 
from morning to evening but whose harvest is not commensurate with the effort and time spent; it conjures the image of a people who are starving, eating at best, once a day after returning from the market (p.49).

On his part, Adepoju, cited in Udoakah asserts that "living conditions in rural areas are relatively poor and remuneratively non-farm employment opportunities are scarce. Besides, rural areas still lack basic social amenities (p.49). Also, Ijere, cited in Nsereka (2018), says that "the word rural...connotes a place with agricultural orientation, with farm houses, barns, shed and other structures of similar purposes (p.125). Rural areas are the undeveloped areas in the hinterland where about $80 \%$ of Africa's population live in the villages, hamlets and hideout... Their main features are malnutrition, abject poverty, mud houses and huts and centuries of criminal negligence by colonial and post-independence government, Uche (1991, p. 17). Rural areas generally refer to areas in a country that are not fully developed. They are areas in a nation where you still have high traditional lifestyles that cannot be found in the urban areas or centres (Asemah and Anum, 2013, p.20).

The experts cited above all agreed that the people who dwell in the rural areas are subjected to poverty, sufferings and do not experience the best that life offers. They are not also exposed to facilities that can enhance their potentials. It means, therefore, that a rural area entails place of residents of and for people whose conditions are in opposite direction with those in the urban centres. Rural areas do not entirely connote poverty, but has to do more with conditions of things that make life meaningful to the people. There are a few wealthy people in the rural areas, but they cannot enjoy electricity, good roads, good hospitals, good schools, banks, markets and good recreation centres. People in the rural areas also have limited access to information purveyors and the mass media. Till date, radio remains the most available source of information to people in the rural areas. However, because of illiteracy most people in the rural area do not understand the information that is transmitted through radio. Also cultural underpinning plays major role in deciding what information to retain, even among those who understand the messages that come through radio.

This is why the author believes that trado-modern communication can be relied on in creating awareness and sensitization of the people on the danger of HIV/AIDS, and also ensure the prevention of Mother-to-child transmission of the virus among Andoni women.

\section{Communication}

Communication maintains and animates life. It is also the motor and expression of social activity and civilization; it leads people and peoples from instinct to inspiration, through variegated processes and systems of enquiry, command and control; it creates a common pool of ideas, strengthens the feeling of togetherness through exchange of messages and translates thought into action, reflecting every emotion and need from the humblest tasks of human survival to supreme manifestations of creativity-or destruction. Communication integrates knowledge, organization and power and runs as a thread linking the earliest memory of man to the noblest aspirations through constant striving for a better life, (MacBride, 1980, p. 3). The above view about communication entails that it is the fulcrum around which life revolves. Life is embedded in it. It could also be inferred from the submission that communication moves life; and in it life is expressed. Communication gives hope when people come together to share experience as they move from their different individual levels to social setting where they are inspired in various ways. The social setting created by communication is enhanced through exchange of messages that create understanding. Omego and Nwachukwu (2013) note it thus:

communication is, therefore, creating meaning. Meaning is the whole aim of communication. If communication does not convey meaning then the whole effort of communication is futile. A test of communication success is when the stimulus as it was initiated and intended by the sender correspondents closely with the stimulus as it perceived and responded by the receiver, and this is not possible without meaning (p.4)

Richards, cited in Ndimele and Innocent (2016, p. 2-3) says "communication is the process by which one mind so acts upon its environment that another mind is influenced and in that other mind, an experience occurs which is like the experience in the first mind, and is caused in part by that experience". By this, communication is viewed as a social process in which one's action affects another through understanding which produces the desired result. Communication connotes a process of sharing meaning and understanding between and among people, aimed at ensuring successful and sustainable social intercourse.

It means, therefore, that there is no communication without meaning sharing and understanding that will bring about successful and sustainable relationship. This is because communication is central to any attempt at inducing change in any society as it provides information that will enable people to understand and appreciate the need to participate in development initiatives, (Ochonogor, 2016, p.71).

\section{Modern communication}

Modern communication, in this article refers to all means of communication involving the mass media. They are 
communication through radio, television, newspaper, magazine and film etcetera. Modern communication also involves the new media. They are all technologically-enabled platforms and succeed among the literate people. They are ubiquitous and known to most people in the world. These communication platforms spread information like the speed of light and penetrate boundaries into homes of people directly or indirectly connected to the messages. They can be categorized into the Print, Electronic and the Social Media. The Print and Electronic Media are further categorized as the Old Media while the Social Media are grouped as the New Media.

According to Orlu-Orlu (2013), print media are the means through which people get detailed analysis or report of event (p.17. The print media have unique characteristics of exemplifying and simplifying complex development issues and challenges largely by virtue of their capacity to explain and illuminate phenomenon as well as the permanence of their information custody, which enables the reader to have access to, read repeatedly and digest the information content (Soola, 2016, p.8). Soola goes further to say that in addition, the print media may also be magnified or miniaturized as pamphlets, posters, handbills, billboards and so made available across various strata of society. In addition, magazine, by being weekly or monthly, can devote more time and resources to researching the problem and providing empirical, quantitative data that further shed light on the phenomenon and its seemingly intractable nature. Generally, newspaper and magazine are elitist in nature. Most importantly, the audience must be literate to access development messages in print. In a developing economy like Nigeria, level of education, level of income and various other socio-economic factors hinder the effectiveness of print media...(Soola, 2002; Ojebode, 2006), cited in Obasanjo (2016, p.118). Magazine is known as the store house of variety of stories, Orlu-Orlu (2013, P.18).

Writing about radio, as one of the Old Media, Soola (2016) notes that radio has continued to enjoy its pride of place as the most popular, though arguably most influential, medium of mass communication, particularly among predominately traditionally, largely non-literate societies where electricity is in short supply and often erratic, (p.8). On the other hand, he says that in spite of being an elitist, expensive and urban-centrist medium, television continues to endear itself to its captive audience by reason of its quadruple advantage of sound, light, motion and simultaneity (p.9). Ndimile and Innocent (2016, p.151) note that the radio is not limited by illiteracy, poverty, or poor infrastructural facilities...Radio programmes are supplemental, that is, we can listen to them while doing other things. The television shares most of the features of radio, but in addition, the television adds the feature of having the ability to back its messages up with images. The television is audio-visual, that is, it presents it messages through sound and light. (p.153). People obtain much of their information from the media which play an important part in selecting which pieces of information to communicate to the public and in addition to giving credibility to information provided through other sources, Dyck and Zingales (2002, p.109).

Social Media (SM) are now household names the world over. Social media are being discussed both at the micro and macro levels of social intercourse. These internet-enabled platforms are also at the heart of economic, political, legal and cultural interactions, among others. Social media have continued to attract huge associates because of their digital nature, Reuben (2018, p.133). Okon (2015) notes the democratization nature of the social media thus:

Within the conspectus of the new media, however, the biggest game changers appear to be the social media. Through the social media, friends, families, colleagues and people of convergent ideologies build networks of interactivity and social exchange with a view to transferring and sharing events on the go. The beauty of it all is that the social media platform allows the voiceless to be heard and the seemingly uneducated to contribute to rational discourse because the rules for structured language appear a bit flexible (p.132).

Social media, therefore, are environments that are open to all, thus blurring the barriers of ownership embargo and economic determinant factors for news making and placement. The only and simple requirements for entering their gates are creation of an account and downloading of the various Apps, as well as weekly and monthly subscription for data, through the various telecommunication networks. Social media create and recreate reality with high speed which enables any pieces of information on them to be available to the heterogeneous but highly interconnected audiences.

Bansal (2009) argued that each evolution in media shifts control farther out of the hands of the persons who operate the media and move into the hands of the people who use it. Control always shifts somewhat more from the one to the many. That each evolution in media technology always shifts control farther away from the one and more towards the many is a historical fact, visible over the millennia (p. 2). Social media are tools for globalization. Their penetrations go into every boundary of the world. Social media represent paradigm shift in how people discover, read and share news and information content, which has in turn brought about the democratization of information and transformed people from being content readers to publishers, (Ezinwa and Okoye $(2015$, p.56). But "an increasing source of concern among communication experts in this respect, is the alienation of the rural communities in the face of modern mean of information delivery" (Nsereka, 2013, p. 25) 


\section{Traditional communication}

Culture is the foundation of communication and traditional communication beautifies culture. They exist together for effective functionality of the society. Traditional communication has always existed side-by-side with the people-whose life, history, monarchy and pastoral existence have been enhanced and sustained through it. MacBride 1980 recognizes this when he notes that since time immemorial, the human race has used primitive, simple forms of communication, which have been enhanced, extended, refined, and are still in use today in all societies despite the continuous invention of new technologies and the increasing sophistication and complexity of interaction between people ( p.47). Similarly, Ukonu and Wogu (2008) maintain that Africa, for all time, has had distinctive, formal mode of social interaction. Proverbially, she has always had sufficient (communication) firewood in her forests to cook her food (p.1).

Traditional communication is, therefore, intrinsic. Its natural pre-eminence makes it practicable among a people wherein it exists. It is a form of communication by the people and for the people. Traditional communication system refers to modes of meaning exchange that are rooted in a people's culture, and which began from the era of preliterate and pre-modern man. Traditional communication encompasses a people's total way of life, including concepts and objects that do not deal directly with communication as a subject (Ukonu and Wogu 2008, p. 5).

Writing about traditional communication, Dede, cited in Ukonu and Wogu (2008) observes that Africa's traditional modes of communication form interplay or synthesis of the traditional customs and conflicts of a community, its harmony and discord, its cultural affinities and disparities as well as its culture-specific values and practices p. 5). According to Nsereka (2013):

the traditional media include the town crier and talking drums, the age-grade networks, traditional religious groups, the symbols of traditional rulership like the staff of authority and the oramedia, that is, the oral folk media. The horns and talking drums, for instance, constitute the nexus between the folk and the mass media in Africa, since like radio, they communicate messages over long distances (.p.4).

Dede, cited in Ukono and Wogu (2008) also notes that these traditional modes include oral traditions like mythology, interpersonal relations or interactions, symbols, signs, oral literature like poetry, storytelling, folktales, proverbs, riddles and jokes, etc, as well as dance, drama, masquerades, rituals, etc (.p.5). No doubt, the traditional modes of communication put the people in the communication realm. This is because the people are familiar with the modes and see them on daily basis. Also, those who operate these modes of communication are people from the same cultural background with the people for whom the messages are intended. Traditional modes of communication are therefore cultural and transactional as noted by Ukonu and Wogu (2008):

when we say that traditional media system is transactional, we mean that this form of communication involves a relay of message by the communicator and a dynamic exchange of meaning and feedback in the communication context. Each participant is giving and receiving information, acting and reacting, agreeing and disagreeing, creating and recreating, pleasing and being pleased or displeased all in a dynamic transaction, (p.40).

Messages from traditional media are adaptable to the experience of rural residents. The nearness of the source, the use of familiar codes, which bring about an exchange of meaning, and the simplicity and familiarity of the content of the message mean that messages are easily useful (p.41).

\section{Integration (Trado-Modern-Communication)}

According to Chukwu, 2006, cited in Nsereka (2013), the argument for absorption of both technologicallymediated communication media and traditional media, for enhancement of the society and the masses, is hinged on "a vision of a society that has no reason to remain in perpetual conflict with those instruments which it can accommodate in the process of streaming our communication systems for greater effectiveness" (p.29). The above submission is very relevant to the issue addressed in this article. Mother-To-Child Transmission of AIV/AIDS has remained threatening in the world, especially in the underdeveloped countries. Consequently, attempts are constantly being made to avoid being in unending conflict with the tools which society can accommodate to ensure effective communication for the overall good of the people.

Therefore, having explored the relevance of the various communication platforms and by implication, their peculiarities and applications, there is need for their synchronization to address some of the issues in the society. Mother-To-Child Transmission of HIV/AIDS is one of the issues that are affecting Nigeria. Rivers State has 5.8 HIV/AIDS prevalence, while Mother-to-Child Transmission is 1 per cent. According to National Agency for the Control of Aids, rural areas in Nigeria have higher rates of HIV than the urban centres. Andoni is one of the rural areas of Rivers State, and its status prompted this work. Having explored the nature of Andoni and her people in page 6 of this work, there is need for strong advocacy to ensure integration of modern and traditional modes of 
communication, in the campaign for the prevention of Mother-To-Child Transmission of HIV/AIDS among women in the area.

Combining technologically mediated communication with the largely interpersonal indigenous communication for greater effectiveness of communication in support of development is the centerpiece of the indigenization framework by which technological media will be selected for application based on their capacity to fit into the indigenous patterns, Ansu-Kyeremeh, in (Nsereka, 2013, p.29). Nsereka adds that a combined use of the interpersonal communication and the modern media leads to interesting socio-cultural results, as using one medium to complement, supplement or reinforce another is necessary for effective integrated rural development.

The above scholars have stressed the role of integrated communication strategy in achieving effective communication and by extension addressing the challenges confronting people in the rural areas amidst HIV/AIDS peril. Their positions do not attempt to diminish the effects of the modern media; rather they have advanced a communication pattern that is appropriate for some people under some kinds of conditions and in some places. This is why Ukonu and Wogu (2008) argue that modern media are fast, versatile, but impersonal, unidirectional, elitist and alienating. Traditional media are credible, integrative, but slow. There ought, therefore, to be a systematic approach to integrating traditional and modern systems... in a complementary fashion (p.49). Generally, the mix media approach remains indispensable for effective media campaign...The mass media especially the radio have always played an important role in promoting modernization and development to people as well as articulating the views of the common man. But the benefits of the mass media do not undermine strength of the traditional media for the same purposes, (p.24).

As equally noted by Jibril, Suleiman, Abdullahi and Mohammed (2018):

Internet mediated HIV/AIDS messages do not help in advocacy against the spread of HIV/AIDS. Many of the respondents argue that the messages do not help in advocacy (74.9\%). Based on this, we conclude that the mere presentation of HIV/AIDS advocacy campaign messages through the internet or ICT would not be enough to stop the spread of HIV/AIDS...It is therefore recommended that other familiar interpersonal communication strategies should be applied to further convince people to adopt the desired attitudinal change necessary for preventing the spread of the disease (p.514

The above empirical submission has further buttressed the need for integration of modern and traditional modes of communication as mechanism for prevention of mother-to-child-transmission of HIV/AIDS among Andoni women of Rivers State. The rural dwellers need information about health care, weather, family planning, agriculture... When the rural dwellers do not get the necessary information, in a well-coordinated fashion, they lose confidence in the government and the society at large ((Asemah and Anum, 2013, p.24). To avoid this, Udoudo believes that a combination of traditional modes of communication amidst the technological-driven world-whether radio, television, newspaper or the new media, if carefully organized and blended, can lead to interesting cultural experience and results, especially where peculiarity of its environment is respected (2017).

\section{Conclusion}

Till date, HIV/AIDS remains life-threatening disease the world over. Nigeria as a country in particular, has continued to make efforts in curtailing and eradicating the endemic disease. Consequently, several measures and programmes have been launched in order to achieve the goal. However, most of the measures and programmes are urban-centered. So, only the educated urban-based people are mostly targeted, while the largely illiterate, poor and vulnerable people in the rural areas are wallowing in ignorance concerning modes of transmission and threat of the disease. When the rural dwellers are remembered, individuals and agencies carrying campaign against the disease disseminate messages meant for them through the mass media. As a result of this, the target audiences are missed and the problem continues.

Considering the challenges posed by the disease and the roles of communication in preventing spread of the ailment, a better communication strategy is, therefore, imperative. Trado-modern communication, based on empirical facts about the merits of their fusion in awareness creation, advocacy and spread of innovation in the society, should therefore, be considered as catalyst for prevention of mother-to-child transmission of HIV/AIDS among Andoni women.

\section{References}

Ansu-kyeremeh, K. (2005). Indigenous communication in Africa: Concept, application and prospects. Accra: Ghana University Press.

Asadu, C. A. (2012). Anatomy of communication for development. University of Port Harcourt Press Ltd: Choba. Asemah, E. S \& Anum, V. (2013). Radio as a tool for rural development in Nigeria: Prospects and challenges, in an International journal of arts and humanities, Ethiopia Vol. 2 (1), 17-35

Bansal, S, K. (2009), Information technology in journalism. New Delhi: A.P.H Publishing Corporation 
Baran, S. J \& Davis, D. K. (2007). Mass communication theory: foundation, ferment, and future: India.

Dede, K. (1997), Traditional communication systems. Owerri: Canun Publishers.

Dyck, A. \& Zingales, L. (2002) The corporate governance role of the media. In World Bank (ed.) The right to tell: The role of mass media in economic development. Washington D.C: The World Bank (pp.107-137).

Ezinwa, A. C. \& Okoye, G. (2015). The knowledge and application of social media in public relations practice in Nigeria. Review of communication and media studies. 1 (2), 56-67

https://naca.gov.ng/fact-sheet-prevention-mother-child-transmission-pmtct-2016, retrieved Dec 12, 2018

https://www.vanguardngr.com, retrieved December 18, 2018

https://www.who.int/news-room/fact-sheets/detail/the-top-10-causes-of-death

Jibril, A, Suleiman G, Abdullahi, A \& Mohammed A (2018) Access and utilization of internet-mediated HIV/AIDS messages among students of the University of Maiduguri, Nigeria, in Ekeanyanwu, N.T (Ed) The Nigerian journal of communication, the journal of the African Council for communication education, Nigerian chapter vol 15 (2)

MacBride, S (1980) Many Voices One World. New York: UNESCO

McQuail D. (2005) McQuail's mass communication theory (fifth edition). London: SAGE Publication.

Ndimele, O \& Innocent, K.H (2016). Fundamentals of mass communication, second edition. Port Harcourt: M\&J Grand Obit

Nsereka, B. (2013). Trado-modern media in grassroots sensitization: the NOA approach. Port Harcourt: Geocella Integ.Serv.Ltd

Nwagbo, C.R and Ubachukwu, P.O. (2001). AIDS-a threat to human society. In Ezekwesili, N, Ubachukwu, P and Nwagbo, C (Eds), Introduction to natural sciences 2, 346-362

Obsanjo, J.O. (2016). The mass media agenda and global warming debate in Nigeria, in Soola, E. Udoudo, A.J \& Ochonogor, I.C (Eds) Issues and trends in environmental communication, 108-123

Ojobo, I.J (2016) The role of communication in waste Management: the eswama experience, in Soola, E. Udoudo, A.J \& Ochonogor, I.C (Eds) Issues and trends in environmental communication. Ibadan: Kraft Books Limited, 304-347

Okon, G.B. (2015). Social media use by two dominant political parties in Rivers State: Their techniques, application and followership. Review of communication and media studies. Port Harcourt. 1(1), 132-142

Orlu-Orlu, H.C. (2013). Media literacy, religion and child upbringing in a multimedia society. Owerri: Hysab Print and Publisher

Oyesomi, K.O. (2010). Making difference in HIV/AIDS awareness for Nigeria's development: The role of the media. In in Okoro, N (Ed) International journal of communication, an interdisciplinary journal of communication, Nsukka, Vol 12 (1), 104-116

Udoudo, A.J (2017) Lecture note on comparative media system, Department of Linguistics and Communication Studies, University of Port Harcourt.

Ukonu,M.O \& Wogu, J.O. (2008). Communication systems in Africa. Nsukka: Charisma Publishers.

Woju, J.O. (2008) Introduction to mass communication theories. Nsukka: University of Nigeria Press Limited. 